\title{
Gladstone and the Irish Civil Service
}

\author{
Martin Maguire
}

Had Gladstone presented home rule as an essential reform in the administration of Ireland rather than as an attempt to redress historic wrongs, then it would have been better argued and could well have achieved greater success. That Dublin Castle provided an ineffective administration was not disputed by any opinion, in fact it had become axiomatic that the Irish administrative system was hopelessly chaotic. Any who came in contact with the Castle were stunned by the disarray. ${ }^{1}$ But it was the inexorable rise in the cost of the Irish administration that most worried Gladstone and offended his own convictions on the proper relationship between the state and the electorate. One of the great political achievements of Gladstone had been in his 18681874 government, when he had established the minimal state as a central value in

British public life. ${ }^{2}$ The civil service of this minimal state was informed by a deep sense of duty to minimise the expenditure of public moneys. This was achieved through competitive entry by examination to the civil service, strict Treasury control of state spending allied with full public accountability for money spent. Under Gladstone the core function of the civil service of raising and spending taxes achieved

${ }^{1}$ Dudley W.R. Bahlman (ed.) The Diary of Sir Edward Walter Hamilton (3 vols; Oxford, 1972), I, 1880-1882, pp. 89-90 [17 Dec. 1880]; p. 290 [20 June 1882] are good examples of the shock that Dublin Castle could induce.

'Jonathan Parry, 'Gladstone, Liberalism and the government of 1868-1894' in David Bebbington \& Roger Swift (eds.) Gladstone Centenary Essays (Liverpool, 2000), pp. 94-112. 
a moral as well as a fiscal dimension. ${ }^{3}$ But this was not the case in Dublin Castle where it seemed the role of civil servants was to encourage the Irish demand for expenditure. Presenting home rule as a necessary moral lesson to teach the Irish frugal self-government would have been more popular in the House of Commons than righting historic wrongs and more consistent with Gladstone's essential conservatism on the role of the state. Penny-pinching and tight-fistedness were more convincing than displays of Gladstonian righteousness. Scattered throughout his great introductory speech of 8 April 1886 there is an argument that, had it been presented as a coherent whole, may well have succeeded in getting the legislation through the House of Commons. ${ }^{4}$ Gladstone argued that as Irish electorate did not have to bear the cost of the expansion in the state's responsibilities in Ireland, their political representatives could freely demand ever new innovations in state activism. Indeed these politicians courted popularity by encouraging the view that the Irish had a right to pillage the British Treasury. The Castle administration, that ought to be animated by a consciousness of the permanent necessity of retrenchment in government, either acquiesced or positively assisted in the attack on the British Treasury. The Irish administration, instead of acting as a restraint on state expenditure, had evolved into a mechanism for aiding and abetting Irish politicians in extracting more and more from the British taxpayer. Few in the Conservative or Liberal ranks would have disagreed with his view that the ability of the poorer country of the United Kingdom to draw without restraint from the pocket of her wealthier partner was actually assisted rather than hindered by the Irish administrative system. Therefore, as Gladstone argued

\footnotetext{
${ }^{3}$ H.C.G. Matthew, Gladstone 1809-1898 (Oxford, 1997), p. 640; John Maloney, 'Gladstone as Chancellor', Journal of Liberal Democrat History, 20 (Autumn, 1998), pp. $12-16$.

${ }^{4}$ Parliamentary debates [PD], Third Series, CCCIV, 8 Apr. 1886, cc. 1050-51; 1072$78 ; 1080-84$.
} 
privately but failed to drive home in the debate, the efficient (that is, cheaper) government of Ireland was as much a British as an Irish problem. ${ }^{5}$ H.C.E. Childers, expressing the Treasury view, was prepared to support home rule for Ireland as a 'welcome relief for the British taxpayer' ${ }^{6}$ Hartington was prepared to admit the necessity for the reform of the Castle and the need for devolved administrative authority. ${ }^{7}$ The urgent need to fundamentally recast the Irish administration was admitted on all sides and so had no politically divisive implications. None could have opposed a proposal to compel the Irish themselves to pay the cost of the interventions that they now constantly demanded. ${ }^{8}$

Comparing the 1886 and 1893 home rule bills it is even more apparent that Gladstone's unchanging core objective was not to devolve legislative authority, but rather to reduce the ability of an Irish executive to draw on the British Treasury. The legislative body went through radical changes. Kendle lists seven significant ways in which the later proposal differed from the earlier. In both the 1886 and 1893 proposals the lord lieutenant, as representing the executive power of the crown, was retained but in the 1893 proposal he was to be assisted and advised by an executive committee drawn from the privy council of Ireland and his term of office was to be fixed at six years. The 1886 bill proposed a complex mix of a single chamber with two orders. The model that was being drawn upon was not Westminster but the Church of Ireland Synod created after disestablishment. The orders could meet and

\footnotetext{
${ }^{5}$ Agatha Ramm (ed.) The political correspondence of Mr Gladstone and lord Granville 1876-1886, II, 1883-1886 (Oxford, 1962), p. 10.

${ }^{6}$ Ibid., p. 396, Granville to Gladstone 11 Sept. 1885.

${ }^{7}$ A.B. Cooke and John Vincent, The Governing Passion Cabinet Government and Party Politics in Britain 1885-86 (Brighton, 1974), p. 111.

${ }^{8}$ Theodore K. Hoppen, The Mid-Victorian Generation, (Oxford, 1998), pp. 673-74; Alvin Jackson, Home Rule and Irish History (London, 2003), pp. 63-64; D. George Boyce, Nineteenth Century Ireland: The Search for Stability (Dublin, 2005), p. 189.
} 
vote separately or together, as they wished. In the1893 bill this had been replaced by two distinct chambers meeting separately. Irish representation at Westminster showed Gladstone to be even more undecided. In 1886 Ireland was to be excluded; the 'out' option. In 1893 Irish representation at Westminster was to be retained but on 'in and out' basis. This was abandoned in committee and Ireland was 'in' by vote of the Commons. $^{9}$

In contrast to woolliness on legislative and representative structures, Gladstone showed a consistent determination to limit the ability of an expansionary Irish state to draw from the British Treasury. ${ }^{10}$ It is clear that despite the rhetoric of 'God's Judgement on England' and 'Justice for Ireland', Gladstone's primary objective was financial rather than legislative autonomy for Ireland. In fact Ireland was to be made to pay for the services of the British civil service under Home Rule. The financial clauses of the 1886 bill imposed a prior annual charge on the Irish budget of $£ 110,000$ for the 'imperial civil service' in Ireland. These were the non-transferred departments such as customs or the ordnance survey, thus charging the Irish taxpayer for the privilege of imperial rule. The pursuit of more economical government under home rule was therefore expected to bear down especially hard on the Irish civil service.

Gladstone had experienced Irish civil servants' ability to combine with Irish politicians against the Treasury when they inflicted a defeat on his 1868-74 government. In 1866 in Dublin a Civil Service Committee memorialised the Treasury with a request for equality with London salaries, a request that was promptly rejected.

\footnotetext{
${ }^{9}$ John Kendle, Ireland and the Federal Solution the debate over the United Kingdom Constitution 1870-1921 (Dublin, 1989), p. 75.

${ }^{10}$ Jackson, Home Rule, pp. 82-83.
} 
The problem with the memorial was not the claim that it made for equality with London but rather the threat to mount a political campaign amongst the Irish M.P.s to put parliamentary pressure on the Treasury should it refuse to accede to their request. This, as the Treasury fumed, was expressly forbidden by official procedures and was 'subversive of all discipline and of the proper subordination which ought to exist in the various grades of the civil service. ${ }^{11}$ However the Irish civil servants were not at all afraid of breaching discipline and, using David Plunket, Conservative M.P. for Dublin University, launched their campaign. Plunket was close to the civil servants and often reflected their views and concerns. ${ }^{12}$ In July 1870 he rose in the House of Commons to ask Gladstone whether he was aware of the statement prepared by a committee of the permanent civil servants in Ireland which showed that a great disparity existed between the scales of salary of corresponding government offices in London and in Dublin and whether he was prepared to redress this inequality.

Gladstone's reply, whilst denying the validity of the comparison between London and Dublin and upholding the Treasury view that valid comparisons could be only with comparable local employers, conceded that were it to be shown that civil servants of the same class were on a poorer pay scale in Dublin than London that would require a fuller examination. ${ }^{13}$ The civil servants then submitted an analysis of the work and salaries of the General Register Offices in Dublin and London, detailing the inferior scales in the former. Shrugging off the Treasury rebuttal of their analysis the staff

\footnotetext{
${ }^{11}$ National Archives, London (NA), T14/38,to the Register General Ireland, 7 June 1866.

${ }^{12}$ See the opening remarks in National Library Ireland [NLI], p. 1289, Charles Henry Brien, 'An Address on some of the influences of scientific enquiry on modern thought delivered before the Civil Service Literary Society 24 Nov. 1873'.

${ }^{13} \mathrm{P} D$, CCII, c. 1620,7 July 1870 .
} 
continued to mount a political lobby of their case. ${ }^{14}$ Aggressive political pressure succeeded where submissive memorials failed and the Irish civil servants eventually got their inquiry.

Charged with investigating specific Dublin departments the inquiry had also to look into the "causes of dissatisfaction which exist amongst the members of the civil service serving in Ireland' ${ }^{15}$ With the formation of the commission Irish civil servants bombarded their departmental heads with memorials asking for improvements in pay, knowing that these would be just as quickly passed on to the Treasury without examination, with a suggestion that they be referred on to the commission. The Treasury had to remind the Castle that 'nothing has occurred to relieve the Irish government or the chiefs of particular departments from the ordinary responsibility of minutely criticising every application for increased salary which is made to them and of submitting to the Treasury those applications only which they themselves believe to be just and necessary'. ${ }^{16}$ The commission immediately opened up the rich vein of ambiguity around the civil service in Ireland, as it was not at all clear what exactly the term 'Irish' civil service meant. The Geological Service in Ireland (GSI) was a very big department. In response to pressure from the GSI staff for inclusion in the inquiry, the Treasury replied that this department was part of the 'Imperial' service and therefore could not be included in an 'Irish' inquiry. Attempting to clarify further this newly-created distinction between the Irish and the Imperial service the Treasury

\footnotetext{
${ }^{14}$ Report of the commissioners appointed...to enquire into the condition of the civil service in Ireland...Parl. Papers 1873, XXII, [c-789], appendix VI.

${ }^{15}$ Ibid., p. 1; P D, CCXVI, cc. 1805-31, 4 July 1873.

${ }^{16} \mathrm{NA}, \mathrm{T} 14 / 43 / 473$, Treasury to the Under-Secretary Ireland, 3 Jan. 1873.
} 
decided that the Irish service were those departments having their centre in Dublin and having a classification of salaries exclusively Irish, all others were 'imperial'. ${ }^{17}$

The evidence of the civil servants to the commission shows a Pooteresque obsession with status and respectability, values which permeated the civil service and were in all probability shared by the commissioners. Civil servants, they complained, were so poorly paid they could not maintain an upright and independent position in society. It was even the case that due to their low salaries some civil servants were compelled to live side by side with artisans rather than amongst the respectable middle classes. Not surprisingly the inquiry found that the causes of dissatisfaction amongst the Irish civil servants were the general inadequacy of their salary scales along with the inferior rates of pay offered to analogous offices in Dublin as compared with London. However the commissioners decided that to determine whether that disparity was justified would require a classification of all the offices in the entire United Kingdom civil service, a task beyond the ability of the inquiry. ${ }^{18}$

The government sat on the report while the Treasury officials dissected it. ${ }^{19}$ In parliament David Plunket once again took up the case of the Irish civil servants. His resolution in the House of Commons asked that the commission having reported that the Irish civil service salaries were indeed inadequate, the Irish civil servants should now be placed upon 'an equality as to remuneration with those performing duties in England corresponding in difficulty and responsibility'. ${ }^{20}$ Plunket, and presumably the

\footnotetext{
${ }^{17}$ NA, T14/44/508, Treasury to Pim esq. MP 1 Jan. 1874; T14/45/222, 9 May 1874. ${ }^{18}$ Report of the commissioners... into the condition of the civil service in Ireland, p. 3. ${ }^{19}$ PD, CCXIV, c. 154 (7 Feb. 1873); CCXV (24 Mar. 1873); CCXV, cc. 345-46 (31 Mar. 1873).

${ }^{20}$ Ibid., CCVI, cc. 1805-31 (4 July 1873).
} 
civil servants who briefed him, were only too willing to admit that a classification of the entire civil service to meet the special case of the Irish civil service was impractical. He assured the House of Commons that the Irish civil servants would be perfectly content with the simple removal of inequalities between London and Dublin. ${ }^{21}$ The debate shows that support for the Irish civil servants case crossed Liberal and Conservative party boundaries amongst the Irish M.P.s. Plunket was himself a Conservative. He was supported by his fellow conservatives Jonathan (?) Pim, the Conservative M.P. for Cork City and Henry Bruen, Conservative for County Carlow. Liberal supporters were Dominic Corrigan the M.P. for Dublin City and McCarthy Downing, M.P. for Cork County. The supporters of Plunket's motion, in quasi-nationalist speeches, attacked what they saw as the degraded status implied by the inferior salaries of the Irish civil servants. The most striking thing about the government response in the debate is the absence of any contribution from either the Lord Lieutenant or the Chief Secretary Ireland. Instead the government side was monopolised by the Chancellor Robert Lowe and by Gladstone, thus signalling that the government viewed this as an economic rather than Irish debate. The Treasury analysis of the report informed both Lowe and Gladstone's response. ${ }^{22}$ Lowe first dismissed the view that prices should determine salaries. Only the immutable law of supply and demand could regulate salaries. Second, he offered as a concession that the Treasury might be directed to examine in accord with its usual procedures the staffing and salary levels of the various Irish offices whilst admitting that the salaries in the RGO were self-evidently too low and required immediate redress. Gladstone strongly supported Lowe although he was in fact to force his resignation as

\footnotetext{
${ }^{21}$ Ibid., cc. 1809-10.

${ }^{22} \mathrm{NA}, \mathrm{T} 14 / 44 / 152$, Lingen to the Chief Secretary Ireland, remarks upon the civil service commission fourth report, 3 May 1873.
} 
Chancellor within the month and absorb the office into his own. Gladstone in a very defensive speech said that the government advocated the national interest whilst the Irish M.P.s had been representing the cause of a class, but that Irish pressure would not deflect his government away from the correct and economical practice toward a wholesale revision of Irish civil service salaries.

The government suffered a humiliating defeat in the vote on Plunket's motion. The defeat was due less to sympathy for the Irish civil servants amongst the Conservatives than loss of control of the House of Commons by the Liberals. ${ }^{23}$ This was a tired government running out of energy and ideas. It was weakened by its own badly managed resignation and resumption of office earlier in March. Its reputation for sound fiscal policy was struck a blow by irregularities in the Post Office Savings Bank and the scandals that surrounded the award of a contract for the telegraph to South Africa. ${ }^{24}$ In the aftermath of the defeat the government made it clear that regardless of any House of Commons motion they intended to adhere to the orthodoxy of market forces and periodic Treasury scrutiny of all departments. ${ }^{25}$ Before leaving the 1873 debate it ought to be noted that the Irish civil servants were, in comparison to other Irish salary levels, quite well-paid. What rankled with the Irish civil servants was the gross inequality with London levels in a service that was supposedly becoming uniform. If merit was the criterion for entry and promotion in the civil service then unequal salaries for the same post in London and in Dublin implied a deficit of merit in Dublin civil servants.

\footnotetext{
${ }^{23} P D$, CCXVI, cc. 1805-31, 4 July 1873 for the full debate.

${ }^{24}$ Matthew, Gladstone 1809-1898, pp. 220-21.

${ }^{25} \mathrm{PD}$, CCXVII, cc. 149-50, 10 July 1873.
} 
As he prepared the 1886 home rule proposal one of the immediate benefits Gladstone anticipated therefore was that it would free the British state of a large part of the cost of the Irish civil service. In apologising to his Chancellor Lord Herschell for the 'very good pecuniary terms' offered to civil servants by his home rule bill Gladstone point out that the British exchequer 'shall be well paid in being relieved from the constantly growing charge of the Irish civil service and in the reversion of a large part of that very claim upon our money'. ${ }^{26}$ As the bill was being discussed at Cabinet amongst the 'cardinal points' agreed was that civil government would continue as it was until altered by arrangement, with some protection for the Dublin civil servants when those inevitable alterations did occur. ${ }^{27}$ Gladstone indicated that to 'meet the case of the civil service' he envisaged a provision to fix the compensation that might be given to persons dismissed by the new Irish government, suggesting that he expected a significant number of such dismissals. ${ }^{28}$ Earl Spencer, Lord Lieutenant of Ireland, suggested that the legislation ought to contain 'a better refuge for civil servants who may be driven out by the new Government of Ireland'. ${ }^{29}$ James Bryce, the Liberal politician and former Professor of Law at Oxford, suggested a clause to maintain the civil service unchanged for three years, with provision thereafter to retire on pension. ${ }^{30}$ In introducing the bill Gladstone's initial suggestion was that the civil service would be retained for two years only, to ensure stability. After the two years

\footnotetext{
${ }^{26}$ Matthew, Gladstone Diaries, XI, p. 524, Gladstone to Lord Herschell, 4 Apr, 1886. ${ }^{27}$ Cooke and Vincent, Governing Passion, p. 395.

${ }^{28}$ Matthew, Gladstone Diaries, XI, p. 525, Gladstone to Lord Herschell, 5 Apr. 1886. ${ }^{29}$ Peter Gordon (ed.) The Red Earl the Papers of the Fifth Earl Spencer 1835-1910, (1986), II, p. 112, Lord Spencer to Lord Herschell, 5 Apr. 1886.

${ }^{30}$ Bryce Papers, National Library of Ireland [NLI], Ms 11009, 'observations on legal points connected with the home rule bill'.
} 
both parties, the civil service and the Irish government, would be 'free to negotiate afresh' ${ }^{31}$

In the initial draft of the home rule bill under the heading 'civil powers' Gladstone envisaged that the Irish Parliament should have complete autonomy to pass 'any bill touching civil offices in Ireland and the mode of appointment thereto'. Under the heading 'executive powers' he provided that all the civil appointments already made would continue unchanged until altered by statute, except that the costs would now be charged upon the consolidated fund for Ireland. ${ }^{32}$ Thus there was generally expected, and accepted, that a home rule government would have complete control of its civil service and that this would lead to a significant reduction in numbers.

In the 1886 Bill sections 28,29 and 30 dealt with the civil servants. ${ }^{33}$ Section 28 expressly stated that the Irish civil service would continue to hold the same offices, with the same or analogous duties, at the same salaries, allowances and pensions as before but the cost to be charged to Irish custom and excise receipts or to the consolidated funds. Section 29 provided for voluntary retirement, but after only two years of service under the home rule government, a year less than suggested by Bryce, perhaps to ensure finality and to meet the possibility of the return of a Conservative government in the next general election. Pensions in the cases of retiring or dismissed civil servants were to be calculated by the Treasury according to the never completed fourth schedule. Section 30 provided that existing pensions would, so far as possible, be drawn out of Irish revenues. It is clear that the main concern in drafting the bill was

\footnotetext{
${ }^{31} P D$, CCIV, cc. 1072-3, 8 Apr. 1886.

${ }^{32}$ Matthew, Gladstone Diaries, XI, pp. 671-72, 31 Mar. 1886.

${ }^{33} \mathrm{~A}$ bill to amend the provision for the future government of Ireland [49 Vict.]
} 
to ensure that the Irish Parliament would bear the future cost of the Irish civil service along with any pensions consequent on dismissals, thus ensuring a prudent and cautious approach to both dismissals and recruitment. In doing that Gladstone may well have been responding in part to the fears of the Irish Unionists. In February their parliamentary leader Major Saunderson had outlined their objections to home rule. Acknowledging that the question of whether home rule would be good or bad for Ireland was, in itself, a matter of opinion, he forcefully outlined his objections to the home rulers themselves and his fear that once in control of the administration they would make a total sweep of all appointments and re-introduce the worst evils of corrupt patronage appointments. ${ }^{34}$

The 1886 home rule bill did not reflect any analysis of the function of an Irish administration. It contained no provision for any ministerial or departmental structures but simply proposed to distribute the government of Ireland between Dublin and imperial administrations. Clearly it was expected that the vast bulk of the civil service in Ireland would be transferred to the home rule administration. When asked for a list of the civil appointments which would be 'put at the disposal of the Irish government' John Morley, the Chief Secretary, indicated that the intention was that 'the whole of the Irish civil service would be transferred, with the exception of those who may be in the service of the imperial government', though he assured 'provision was made for those whose service may be dispensed with'. ${ }^{35}$ Four days later when pressed to list the government departments that would be transferred to the Dublin government, Morley remained quite vague, indicating that the answer depended on the view that would be taken by an Irish executive of its requirements. In

\footnotetext{
${ }^{34} P D$, CCII, c. 672,18 Feb. 1886.

${ }^{35}$ Ibid., CCCV, cc. 1826-27, 24 May 1886.
} 
terms of personal and grades those transferred would include heads of departments, superior appointments, clerical staff, servants and messengers. Morley also referred briefly to a problem that was to become more intractable; what exactly was a "civil servant'? Morley offered three qualifications of a civil servant; an official whose whole salary is voted by Parliament, whose whole time is at the disposal of the public and whose appointment carries a pension or gratuity. ${ }^{36}$ As was to become apparent, that neat definition did not even approach the reality of the Irish civil service.

Civil servants, it was axiomatic, would always support a government policy, even if they disagreed with it. The Dublin civil servants seemed to have been ill-prepared for the 1886 home rule bill. Some, no doubt, could anticipate improved promotional prospects. There was some home rule sympathy at the top of the Castle bureaucracy; E.G.Jenkinson the head of the Criminal Investigation Division, and Sir Robert Hamilton the Under-Secretary, were considered very pronounced home rulers during the caretaker ministry of $1885 .{ }^{37}$ On his appointment as Under-Secretary Hamilton had been considered one of the best civil servants in Whitehall. ${ }^{38}$ However for the lower ranks the emphasis which the Liberal government put upon economy, and the virtual certainty as it seemed of wholesale dismissals by an Irish government wholly dependent on its own financial resources, can only have been threatening. In concrete terms what the bill offered the Irish civil service was nothing more than security for pensions already earned. The best that the civil servants could hope for was an improvement in the terms on which they might be dismissed. During the protracted 1886 home rule debate it became apparent that the Irish civil service as a whole had

\footnotetext{
${ }^{36}$ Ibid., CCVI, c. 310, 28 May 1886.

${ }^{37}$ J.L. Hammond, Gladstone and the Irish Nation (London, 1964) pp. 435-36.

${ }^{38}$ Ibid., p. 350.
} 
few political friends and the treatment of the civil service failed to make an impact on the debate. There was a general cross-party agreement that, whatever about the political merits of home rule, the Irish administration was in need of a thorough shake-up. The duty of the British state extended no further than making sure that that shake-up was not any more painful for the civil servants concerned than was necessary. The bill itself and the debate in the Parliament brought home to the Irish civil servants their dispensability and separate status within the United Kingdom and encouraged a consciousness of that status. Previous organisation and agitation by them as a body had been fitful, focussed on pay, and conducted under the hostile eye of the Treasury. Home rule touched on fundamental issues of security and status and yet the Irish civil service proved slow to react. Luckily the 1886 bill failed, but the continuance of the future possibility of home rule necessitated, and made acceptable, the emergence of a more organised Irish civil service representation. The fact was that despite being a tradition-laden service, civil servants had no rights as such. All civil servants were employed 'at the pleasure of the crown' and therefore liable to be dismissed at any time without notice or redress. Civil servants were pensionable but nevertheless had no absolute right to a pension. Pensions remained as granted by grace and favour. The security enjoyed by civil servants was based on the good faith and practice of the government, which any cynic within the Irish civil service might justly set at nought. The fate of Sir Robert Hamilton was a further lesson on the fundamentally insecure status of the Irish civil service as well as a warning that it would be a foolish civil servant that became too closely identified with government policy. When Hamilton, a Scot in the Admiralty, took the post of Under-Secretary after the murder of Burke he had been acclaimed for his courage and sense of duty. In the home rule debate nationalists often cited him as a supporter and advisor to 
Gladstone on home rule. With the defeat of the home rule bill The Times began a campaign to have him removed from the Irish Under-Secretaryship, though this was now a post considered part of the permanent civil service. Despite the opposition of Lord Lingen of the Treasury and of some few supporters from within the Irish civil service, who were alarmed that a civil servant would be punished for too enthusiastically supporting government policy, Hamilton was kicked upstairs to become governor of Tasmania. This was about as far away from Ireland as he could be posted. In fairness it ought to be noted however that most Irish civil servants who feared being driven out by a National League government precisely because they would not be seen as supporters, would have had little sympathy for Hamilton who at least secured a better post and was assured a generous pension. ${ }^{39}$

With the return of the Liberals to government in 1892 a second home rule proposal was expected. The Chief Secretary, John Morley, was under pressure from the Irish M.P.s T.M. Healy and William O'Brien who had both been advocating a different strategy for the Irish administration since the failure of the 1886 home rule proposal. Instead of waiting for a successful home rule act to transform the Irish government they had been separately urging executive use of the power of patronage to eradicate Unionist power in Dublin Castle through the recruitment and promotion of Catholic nationalists as civil servants. ${ }^{40}$ Morley immediately began to infuse the Castle with Catholic civil servants, but more as way to dilute the resistance that he anticipated any home rule proposal would raise. He was made well aware of the profound hostility to

\footnotetext{
${ }^{39}$ See The Times, several editorials and letters July-Nov 1886.

${ }^{40} P D$, Fourth series, XI, cc. 758-59, 20 Apr.1893; Frank Callanan, T.M. Healy, (Cork, 1996), p. 419.
} 
home rule amongst the Castle officials. ${ }^{41}$ Gladstone was much taken with the idea of 'Drummondizing the administration of Ireland' in preparation for another home rule attempt. Thomas Drummond had served as Irish Under-Secretary under the Earl of Musgrave in 1835 and was therefore effectively the head of the Irish civil service. A Benthamite technocrat he had cleaned the Castle of Orange Order influences whilst promoting some able Catholics. But he was principally concerned with bureaucratic efficiency, which meant centralising and consolidating power within the Irish administration. ${ }^{42}$ In Gladstone's mouth 'Drummondizing' was an ambiguous phrase which could mean either Morley's policy of promoting Catholics or a policy of promoting ruthlessly efficient technocrats. ${ }^{43}$

In framing the second home rule bill Gladstone was even more vehement on the necessity to reduce the cost of the Irish civil service. In July 1892 in correspondence with Lord Spencer he referred to the need to fundamentally recast the administration in Dublin Castle. ${ }^{44}$ In Cabinet Gladstone stated as one of the principles of the home rule bill that it must achieve savings in the cost of the Irish civil service. ${ }^{45}$ Introducing the second reading of the bill he returned once again to the theme of the cost of the Irish civil service, describing it as 'incredibly, almost immeasurable wasteful' and asserting that 'the civil government of Ireland costs twice as much per head as that of the greater country'. ${ }^{46}$ George Trevelyan, Scottish Secretary and son of the reforming

\footnotetext{
${ }^{41}$ John Morley Papers, University of Oxford, Bodleian Library. Ms Eng.d. 3449, notebook diary, July 1891, f. 33; on civil service hostility to home rule see Ms Eng. d. 3450, f. 107, 28 July 1892.

${ }^{42}$ Alvin Jackson, Ireland 1798-1998 (Oxford, 1999), p. 45.

${ }^{43}$ John Morley papers Ms Eng. d. 3450, notebook diary, ff. 65-67, 12 July 1892.

${ }^{44}$ Matthew (ed.), Gladstone Diaries, XII, pp. 40-41, Gladstone to Lord Spencer 13 July 1892; Gordon (ed.), The Red Earl, ii, pp. 209-10.

${ }^{45}$ Matthew (ed.), Gladstone Diaries, XIII, p. 184, Cabinet meeting, 20 Jan. 1893. ${ }^{46} P D, \mathrm{X}$, cc. $1604-6,6$ Apr. 1893.
} 
civil servant of the 1850s, Sir Charles Trevelyan, further developed this theme. In answer to the opposition taunt that in creating a new Parliament and a new executive the home rule bill rather than make any savings would double expenditure, Trevelyan minimised the probable cost of the new Parliament. Pointing out that Ireland already had an executive he then detailed the scope for savings in the administration, where 'very large economies' could be made even taking account of the cost of pensions for retired civil servants. Trevelyan insisted that 'there is everywhere a field for economy, which will endure long after these temporary pensions have passed away'. ${ }^{47}$ Thus it was absolutely clear that home rule would and must mean a steep reduction in the size of the Irish civil service and therefore dismissals on a large scale. This insistence that the Irish civil service was over-manned and due a severe reduction raised in the mind of every individual civil servant the question as to whether he would himself be retained. It was the seemingly virtual certainty of dismissals that was foremost in the minds of the Irish civil service as they began to organise a response to the second home rule bill.

The 1893 bill as first introduced to the House of Commons in February, provided that the permanent civil servants of the crown would continue to receive the same salaries, gratuities, and pensions and be required to perform the same duties or analogous duties as before for a transitional period of three years. After the three years the officers might retire, or might be required to retire by the Irish government, on terms which would be in accordance with the fifth schedule of the bill, which remained blank. ${ }^{48}$ Though the language of the bill might imply that those civil servants who

\footnotetext{
${ }^{47}$ Ibid., cc. 1913-16, 10 Apr. 1893.

${ }^{48}$ A Bill To Amend The provision For The Future Government Of Ireland [56 Vict.] (1893), sections 26-28. .
} 
were retained would retain their status and conditions, Morley made it absolutely clear that there could be no guarantee of continuance of current conditions or status beyond the transitional period. ${ }^{49}$ After the transition period the Castle apparatus was on its own and many could anticipate a 'clean sweep' when full authority was passed to an Irish executive. For the civil servants who were retained after the transition period their situation would be that they would cease to be servants of Her Majesty and would be starting afresh with a new government with whom they would have to bargain anew. ${ }^{50}$ The second division clerks of the Irish civil service, though almost certain to face a dramatic reduction in numbers, had the security that they were, since the Lyon Playfair reforms, the servants of the civil service commissioners of the United Kingdom and would be therefore entitled to re-deployment within Great Britain, should they not be required by the Irish government. ${ }^{51}$

The agitation amongst, and on behalf of, the Irish civil service arose mainly from the relatively small number of higher civil servants, the heads of departments and senior officials, and included the professional grades, about five hundred in all. ${ }^{52}$ This represents a highly conscious organisation at the top levels of the Irish administrative apparatus. As a result of their campaign the impact of the home rule bill on the Irish civil service received a much wider debate, and greater sympathy, than had been the case in the 1886 bill. With the first reading of the bill a delegate Committee of Permanent Civil Servants in Ireland was formed, numbering eighty in all, elected by and representing virtually every profession, department and office of the Irish

${ }^{49} P D$, XI, c. 903, 21 Apr. 1893.

${ }^{50}$ Bryce papers, Bodleian Library, 214/90-94, memorandum of the Irish Land Commission, 30 May 1893.

${ }^{51} P D$, XII, cc. 4-6, 19 July 1893.

${ }^{52}$ Bryce Papers, NLI, Ms 11009(4) 'financial scheme of the home rule bill, 13 Apr. 1893'. 
administration. ${ }^{53}$ The delegate conference then elected an executive committee.

Though the Treasury continued to refuse to countenance any trade union organisation within the civil service as a whole, the question of what protection and pensions would be offered to Irish civil servants in the proposed home rule legislation was allowed to become the key issue organising and mobilising those civil servants in a quasi-trade union.

At the request of the civil service committee Morley delayed the publication of the schedule setting out the compensation terms for the Irish civil servants. ${ }^{54}$ On the 1 April the civil service delegation, led by George Morris, President of the LGB, composed of some of the highest-ranking civil servants in Dublin Castle, met with Morley. ${ }^{55}$ They carried a list of suggested amendments to the bill, designed to protect the interests of the Irish civil service. It was generally supposed that an Irish government would purge the civil service, with every encouragement from the British government, and that the role of the legislation was to guarantee pension entitlements. The legislation was framed as if home rule was a standard abolition of a government department. Such abolitions had become more usual within British administration. Abolition terms offered security for pensions already earned and usually also offered additional years as compensation for loss of office. As well as fighting for better terms for abolished offices the committee wanted to include an option for civil servants themselves to retire voluntarily with compensation. Additionally they wanted additional compensation for professionally qualified civil servants who had abandoned private practice to enter government service. The committee was also

\footnotetext{
${ }^{53}$ NLI, Ir 3511 c. 11 'committee of permanent civil servants in Ireland'. ${ }^{54} \mathrm{PD}, \mathrm{X}$, c. 1317,28 Mar.; c. 1505, 30 Mar. 1893.

${ }^{55}$ Ibid.; The Times, 3 Apr. 1893, p. 8.
} 
unhappy that the Treasury retained ultimate discretion over the decisions on all pensions awarded. Thus the strategy adopted by the civil service committee was to accept the government view that home rule was, administratively speaking, a process of departmental abolition and to fight for the best terms possible. With the publication of the fifth schedule, it became clear that though the terms on offer to the civil service were an improvement on those of 1886 the improvements were minimal. ${ }^{56}$ The civil service committee had requested that officers forced to retire should get a pension equivalent to three-fourths of his salary if he had less than 25 tears service, along with a gratuity of one year's salary. If the length of service was over 25 years then a pension should be equal to his salary at the date of retirement. Where an officer was not forced but still opted for retirement then a pension should be granted, depending on length of service, of one-half to three-fourths of salary. What the government offered was a pension varying from one-seventh to two-thirds of salary, with no gratuities, and an absolute limit of two-thirds of pay on any pension awarded.

For the professional civil servants the committee also wanted a facility for calculating added years for professionally qualified persons who had left practices in order to take up government employment, but this was not granted. Nor were they offered, as they asked, that those civil servants kept on by the Irish government would retain the option to retire at any point in the future. The committee also wanted some guarantee from the United Kingdom government, with whom after all they had some sort of contract of employment, for the salaries and pensions of civil servants retained under any home rule administration. But at the same time the committee retained a deep distrust of the Treasury and its discretionary powers in regard to pensions, which were

\footnotetext{
${ }^{56}$ Return...of proposed fifth schedule and sixth schedule, part II. Government of Ireland Bill dated 7 Apr. 1893, Parliamentary papers 1893-95, LXXI.
} 
all retained in the legislation. What the civil servants wanted in summary, were guarantees as to status, salary and pensions, and security for any future salaries and pensions which would be dependent on the votes of an Irish legislature, which meant therefore some sort of continuing imperial guarantee. What the civil servants did get was an increase in the transition period from three to five years. They also got a useful innovation in the shape of a joint committee of the Treasury and the Irish government with the power to determine claims of wrongful dismissal brought by civil servants against the Irish executive during the five years. Though the civil servants of $1893 \mathrm{did}$ not yet see the potential of it, the monopoly on civil service matters enjoyed by the Treasury had been broken. ${ }^{57}$

The Committee of Permanent Civil Servants in Ireland then prepared a very detailed and substantial 'response to the government proposals on home rule as regards the effect on civil servant", and despatched the Chairman, T.W. Grimshaw of the RGO, and the Secretary Arnold Graves, of the Charitable Donations and Bequests Office, to London to begin a political lobby at Westminster. ${ }^{58}$ In comparing the points in the civil servants' own response and the points made by the Conservatives in debate, and in the Conservative newspapers, it is apparent that these Irish civil servants were very effective lobbyists.

As well as relentlessly pushing the demand for enhanced security, even to the extent of pensions at full pay for those compelled to retire, and arguing against the government proposals line by line, the civil service response also made a general statement of the sense of grievance felt by the Irish civil service. The theme running

${ }^{57}$ Ibid.; NLI, Ir 3511 c. 11 'committee of permanent civil servants in Ireland'. ${ }^{58}$ Ibid. 
through their statement is that it was the permanent status of the employment that induced most, if not all, civil servants into service. This was especially true of professionally qualified men who had exchanged the possibilities of advancement in a private career for the securities of a civil service position. With the government suggesting that large reductions would have to be made in the Irish establishment and that a large number of civil servants would be retired at the same time, most of them could not hope to gain employment in a poor country like Ireland. Many, confident of secure lifetime employment, had taken out leases on property and insured their lives and undertaken other responsibilities which, on the terms offered, they could not afford to sustain.

The civil service statement wanted better compensation for the ordinary civil servants, more generous terms for the many professionals who had been recently recruited in the many new posts created under the recent policy of constructive Unionism, and better commutation terms for those who opted to capitalise their pensions and thus begin a new career. They wanted also the option for civil servants to transfer to England to analogous posts. The threat was also implied that the entire body of civil servants, faced with the choice of an inadequate but secure imperial pension if they choose to retire immediately, or an unsecured future salary from an Irish government, would choose retirement now, thus denuding the administration of all its experienced officers. $^{59}$

\footnotetext{
${ }^{59}$ Ibid., p. 12; The Times, 3 Apr. 1893 'letter from an Irish civil servant., p. 8; Bryce papers, Bodleian Library, 214/90-94, memorandum of the Irish Land Commission, 30 May 1893.
} 
The second stage debate opened with the fifth schedule, which detailed the terms on which civil servants would be compensated on retirement, still blank. ${ }^{60}$ Much the most effective and cynical use of the question of the Irish civil servants was made by A.J. Balfour who, when he was formerly Conservative Chief Secretary for Ireland, had been contemptuous of their abilities. During the second reading he travelled to Dublin to speak at a meeting of the Irish Unionist Alliance at the Leinster Hall. The main and best point he made was that strictly speaking there was no such thing as an 'Irish' or 'English' or 'Scottish' civil servants, all were imperial civil servants in a single civil service not divided by nationalities. This was true for the mass of the second division clerks, but for the rest of the Irish civil service it was not true. The Irish civil service, it had been long maintained by both Liberal and Conservative commentators, was anomalous and the autonomous boards, which were the mainstay of the Irish administration, were largely an Irish device. Nonetheless the point was well made and received with cheers. In condemning the plan to hand the Irish civil service over to 'their deadliest and most determined enemies', many of the points he made were taken from the Irish civil servants statement; emphasising the betrayal of the implied exchange of low pay for security and a pension, the destruction of chances of promotion, the burden of commitments entered into in the expectation of a life-long career, commitments which would be unsustainable on the terms of compensation offered. ${ }^{61}$ The Times took up these points and, repeating the theme that the civil servants were officials of the imperial service, linked the "shameful betrayal of the landlords' (a reference to the land purchase acts) with the 'abandonment of the civil servants of the Crown'. ${ }^{62}$ The presence of at least one senior civil servant at the

\footnotetext{
${ }^{60} P D$, X, c. 1597,6 Apr. 1893.

${ }^{61}$ The Times, 10 Apr. 1893.

${ }^{62}$ Ibid.
} 
Leinster Hall meeting was raised in the House of Commons, but the cheers that Balfour's eulogy of the Irish civil service raised indicates that there were a great many more of them present. ${ }^{63}$

The committee stage on the civil service clause 28 and the related schedule, which the government might have hoped would be relatively non-controversial and therefore brief, took a full three days of debate from the 17 to 19 July. As the debate progressed it grew more and more fractious. Morley, in introducing the clause admitted that the terms were not acceptable to the civil servants affected but that, whilst he felt a responsibility to be fair, equitable and generous to the civil service, he was bound not to impose an unreasonable or excessive load of financial responsibility on the Irish government. Morley offered as guiding principles for the clause that the civil servants were to be protected from capricious dismissal or reductions in salary whilst the Irish government had to be protected from sudden en masse retirement and from a sullen and inefficient service. To meet this principle the bill gave de facto control to the Treasury of the number of civil servants that might resign or be required to resign, for five years. The scales for calculating compensation payment for those civil servants either dismissed or who choose to resign within the five-year period, though based on the standard abolition terms, were generous in the extent to which they exceeded those terms. A civil servant with 25 years service could opt to retire on a pension of two-thirds of the salary he would have reached at the end of the five year transition period, even if he choose to retire immediately. ${ }^{64}$

${ }^{63} P D, X$, cc. 448-49, 17 Apr. 1893.

${ }^{64}$ Ibid., XI, cc. 1779-89, 17 July 1893. 
The Unionist opposition attacked the clause from two directions. First, the Irish Unionists put the case for expanding the class of civil servant included in the clause. A strong case was put for the 12,000 national school teachers, or at least the Protestant teachers. Second, the Conservatives, taking up a theme of the Irish Civil Service Committee, returned again and again to the implicit contract between government and civil service and the breach of faith that home rule entailed. Balfour began by refusing to accept that home rule was simply a departmental reconstruction. It was, he insisted, a great official revolution in which there would be a vengeful clearing out of the Castle under the guise of economy and that therefore the terms on offer were wholly inadequate as compensation. His amendment proposed that all dismissed or resigned civil servants would have a right of relocating to a corresponding post in England or Scotland. Lord Randolph Churchill and T.W Russell supported the theme of a breach of the rights of civil servants, their 'freehold' in office. Gladstone, Morley and Fowler of course vehemently denied the very concept of civil servants having any 'rights', nonetheless government amendments tended to extend the security offered to the Irish civil servants, thus granting the effect whilst denying the fact of 'rights'. This in turn infuriated both Liberals and Irish Nationalists. Henry Labouchere worked himself into a fury at the thought of a legion of Irish ex-civil servants living lives of pensioned idleness because they happened to dislike government policy. The Nationalist M.P.s Luke Hayden and John Clancy exposed the contradictions in the compensatory clause. The very foundation of the home rule case was that Ireland was inefficiently administered under the British regime. Since Gladstone's 1886 bill it had been asserted without contradiction that Ireland was burdened by an expensive and bloated apparatus and that home rule addressed that problem by substituting native rule for Castle misgovernment. 
Logically therefore it was Britain ought to pay any compensation offered to their imposed, inefficient and superfluous civil servants. The whole tendency of the government was to erode the already small Irish budgetary surplus by saddling the Irish executive with a burden of compensation created by British misgovernment. The anxiety of the government to assuage the fears of the Irish civil service did lead to one extraordinary innovation. Morley, to meet the anomalous case of model schoolteachers and petty session clerks, introduced an amendment to include any officer who 'though not in the permanent Civil Service, is in the public service of the Crown' within the terms of compensation. ${ }^{65}$ This new category 'the public service of the Crown' was extremely vague and once introduced had the potential to expand endlessly. For instance, it was a category that could and would be successfully applied to the servants of the Congested Districts Board and the education boards. ${ }^{66}$ It was apparent that the tendency of the debate was for the opposition to agree with the government in any amendment that enhanced civil service security or enlarged the categories entitled to compensation, much to the fury of the Irish nationalists who could see the meagre Irish surplus disappearing in pensions.

By any measure the Irish civil service could be pleased with its progress during the home rule debate of 1893. An organisation was formed which had lobbied a reluctant Chief Secretary and had succeeded in making the status and security of the Irish civil service an issue of debate. Intense political lobbying by civil servants, which formerly had been considered gross insubordination at best and subversion at worst, had been

\footnotetext{
${ }^{65}$ Ibid, XII, c. 7, 19 July 1893.

${ }^{66}$ NA, TS $18 / 235$ treasury solicitor papers: civil service provisions under the government of Ireland act 1912, 'letter 6/2/1912 Greer to Chief Secretary'.
} 
recognised and accepted in the Irish case. ${ }^{67}$ The separate interests of the Irish civil servants, it had been indirectly admitted, were not guarded adequately either by the Treasury or by the government. The government had been made to offer some significant improvements in the terms of the bill, but this had been mainly in extending those civil service grades covered by the terms. Civil servants might not, in strict terms, have 'rights' but Irish civil servants had secured protection for something that looked sufficiently like rights as to make the term not worth quarrelling over. However a significant setback had to be recorded in their failure to make the government offer any concession on the transition period of five years. Had the 1893 home rule bill succeeded the Irish civil service would have been faced with the choice of either opting for such terms of retirement as were offered within five years or forgoing them altogether. A more permanent guarantee remained an unrealised objective. There is no doubt that home rule weakened civil service loyalty to the state by introducing an element of conditionality to a relationship that had hitherto seemed as permanent as the state itself.

However with the defeat of the 1893 bill, home rule seemed to have passed into history. Parnell was already dead and his political party was tearing itself apart in the bitter divisions brought on by Parnell's tragic final struggle. Gladstone, the sponsor of two attempts to pass a home rule measure for Ireland, retired in early 1894 and his Liberal Party moderated its commitment to Irish home rule. After the failure of the second home rule bill Morley was still convinced that the only effective reform of

\footnotetext{
${ }^{67}$ National Archives Ireland, Dublin (NAI), CSORP 1893/8082 (20 June) 'application of officers committee'; /8071, (22 June) 'proposals of officers and men reference home rule';/9188 (18 July) 'pensions scale prepared by officers committee'. None of these particular files survive but they indicate the intensity of the lobbying by the civil servants' committee.
} 
Irish government would be home rule and did not attempt any significant changes in the way the Irish administration functioned. He reverted to the strategy of O'Brien and Healy and concentrated on the 'reduction of the old Protestant Ascendancy' through the recruitment and advancement of Catholics. ${ }^{68}$ Despite the supposed operation of controlled entry to the civil service by the civil service commissioners Morley still retained the control of patronage over a great number of Irish posts. ${ }^{69}$ The 1895 general election returned the Conservatives to power.

Under the Conservative policy of 'Killing Home Rule By Kindness' the British state in Ireland took on the task of becoming a development agency. New departments were created, such as the Department of Agriculture and Technical Instruction (DATI), the Congested Districts Board, (CDB) the Irish Land Commission (ILC) and the Local Government Board (LGB). Apart from an increase in the number of bureaucratic functionaries these new departments also required a growing number of professional staff such as lawyers, engineers, architects, valuers, agricultural scientists and instructional experts to oversee land reform, or social and agricultural development. New duties were added to an existing post where possible otherwise a new position was created. By 1912 there were over 40 departments in an Irish administration that was run in parallel by Whitehall and by Dublin. The eleven United Kingdom departments run by Whitehall co-existed with the 29 wholly Irish departments. The great development departments, National Education Board (NEB), Intermediate Education Board (IEB) LGB, CDB and the DATI, were run by civil servants but managed by unpaid boards and were therefore independent of the

\footnotetext{
${ }^{68}$ John Viscount Morley, Recollections, 2 vols. (London, 1918), i, pp. 338-40. ${ }^{69}$ Morley papers, Bodleian Library, Ms Eng. c. 7080, appointments book, ff. 76ff., 1892-95.
} 
political head of the Irish administration, the chief secretary Ireland. In the 50 years between 1861 and 1911, when the Irish population declined by 32 per cent, the number of Irish civil servants grew by at least 350 per cent. ${ }^{70}$

The Treasury found the task of curbing the expansion of administration and expenditure, its primary task in Britain, impossible in Ireland where the function of the state seemed to be to spend on a vast scale. The Public Accounts Committee (PAC) of the Commons was just as unsuccessful in curbing Irish expenditure. In 1902 the PAC was clearly infuriated by unauthorised and excessive expenditure in the Irish departments. When it was pointed out that these departments were all autonomous and there was no single official who could answer for them, and that the PAC would have to have all the separate accounting officers to London if it wished to pursue the question, it decided to retreat. The Irish accounts became a torture that the PAC had to undergo each year and from which it seemed there was no relief. ${ }^{71}$ As the permanent head of the LGB, Henry Robinson, noted (with some hint of satisfaction) the Treasury mandarins 'grew to hate the name of Ireland'.

In the aftermath of Gladstonian home rule the character of the Irish civil service changed with a much more professional and interventionist ethos becoming apparent. The dominance of the legal offices was weakened. The state began to seem less an

\footnotetext{
${ }^{70}$ Accounts and Papers (British Parl. Papers, 1890-91, XCV) Population (Ireland). Census of Ireland 1891, part II, General Report, with illustrated maps and diagrams, tables and appendix, p. 22; Accounts and Papers (British Parl. Papers 1912-13, CXIV) Population (Ireland) Census of Ireland; 1911, General Report, with tables and appendix, Tables 19 \& 20. W.E. Vaughan \& A.J. Fitzpatrick (eds.) Irish Historical Statistics population 1821-1971 (1978) p. 3.

${ }^{71}$ Public Accounts Committee reports and minutes of evidence, Parl. Papers 1902, V, 4014-37; 1903, V, 2-14; 1904, V, 2197-2209; 1908, VI, 2485-2588; 1909, VI, 12661298.
} 
apparatus of domination over Irish society and more one of service. However the home rule debate had irrevocably broken the close identity between the Irish civil service and the state. Despite the insistence that there was a single United Kingdom civil service no civil servant could be in doubt that Ireland was different and that the apparatus in Ireland was considered not only separate but also dispensable. Unionists such as Lord Dunraven and Nationalists such as Redmond all agreed that the Irish civil service was bloated, inefficient and a barrier to the better government of Ireland, whatever form that might take. Irish civil servants had nonetheless developed considerable organisational ability. The Irish civil service had very quickly learned to think of itself as a corporate body united across all ranks by the threat of dismissal implied in the rhetoric of the home rule. On the eve of the third home rule crisis the civil service though assailed on all sides had the organisational foundations to withstand the assault.

Gladstone's influence reached beyond the grave to shape the 1912 home rule bill. ${ }^{72}$ The crisis of the British state in Ireland that unfolded between 1912 and 1922 is beyond the scope of this paper. However it might be noted in conclusion that the Irish civil servants used the crisis and the several variations on home rule that it threw up to extend their organisational and political demand for security for their status. They succeeded in having written into the constitution of the Irish Free State clauses which converted their previous status as serving at the 'pleasure of the crown' into a contractual relationship with legal and therefore defensible status. This was a result which no doubt would have appalled Gladstone but it was one which reflected the

\footnotetext{
${ }^{72}$ Alan O'Day, 'Gladstone and Irish nationalism: achievement and reputation, in Bebbington and Swift (eds.), Gladstone Centenary Essays, pp. 163-93, p. 167.
} 
ability of the Irish civil service to use political influence to thwart any measure that proposed to make them pay the price for Gladstonian tight-fistedness. ${ }^{73}$

\footnotetext{
${ }^{73}$ Martin Maguire, The Civil Service and the Revolution in Ireland 1912-38 'Shaking the blood-stained hand of Mr Collins' (Manchester, 2008).
} 